\title{
ПРАВОВІ ЗАСАДИ ОПОДАТКУВАННЯ ІНДИВІДУАЛЬНОї АДВОКАТСЬКОї ДІЯЛЬНОСТІ: ТЕОРЕТИЧНІ АСПЕКТИ
}

\author{
ОБЛОВАЦЬКА Наталія Олександрівна - старший викладач кафедри \\ публічного та приватного права Факультету права та міжнародних відносин \\ Київського університету імені Бориса Грінченка \\ ORCID Id: https://orcid.org//0000-0002-7405-279X \\ DOI 10.32782/NP.2021.2.3
}

Наукова праия присвячена дослідженню правових засад та теоретичних положень оподаткування індивідуальної адвокатської діяльності. Автором проаналізовано теоретичні аспекти визначення правового статусу платника податку при здійсненні індивідуальної адвокатсъкої діяльності та розкрито основні положення законодавства щодо умов реєстращй, обліку та декларування адвокатсъкої діяльності самозайнятими особами та ббізичними особами, що здійснюють професійну діяльність. Окреслено особливості здійснення індивідуальної адвокатсъкої діяльності як окремого виду підприємницької або професійної діяльності.

Розкрито недоліки та прогалини сучасного податкового законодавства щодо декларування доходів ббізичних осіб, набутих шляхом здійснен-

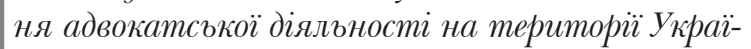
ни, роз'яснено шляхи усунення ицх недоліків та висунуто пропозициі удосконалення законодавиих положень. Запропоновано приведення норм чинного законодавства Украӥни у відповідність до сучасних європейсъких стандартів, що забезпечить належне виконання платниками податків свойх податкових зобов'язань, надходження податків, зборів та обов'язкових платежів до державного або місцевого бюджету, а також передбачить захист прав платників податків самозайнятих осіб або ббізичних осіб, що здійснюють пробесійну діяльність, зокрема, адвокатів.

Ключові слова: адвокатура, інститут адвокатури, адвокатська діяльність, бізична особа, що здійснює пробесійну діяльність, самозайнята особа, індивідуальний підприємець, оподаткування адвокатсъкої діяльності.

\section{Постановка проблеми}

Оподаткування діяльності адвокатів є однією із найбільш значних та найбільш цікавих елементів податкової системи України. Специфіка адвокатської діяльності вимагає особливих підходів до оподаткування цієї діяльності. Функціонування професійної правничої допомоги повинно передбачати різну державну підтримку, у тому числі й сприйнятливе оподаткування.

Мета даної статті полягає у дослідженні теоретико-правових засад оподаткування адвокатської діяльності в Україні, визначенні правового статусу платника податку з доходів отриманих від адвокатської діяльності, а також окреслення оптимальних шляхів оподаткування індивідуальної адвокатської діяльності.

Ступінь дослідженості теми

Дослідженням особливостей адвокатської діяльності присвячені праціМ.Р. Аракелян, Н.М. Бакаянової, Т.В. Варфоломеєвої, Т.Б. Вільчик, О.Д. Святоцького, І.О. Садовської, А.В. Тацій, О.Г. Яновської та інших. Однак постійні зміни у податковому та господарському законодавстві вимагають нових досліджень для обгрунтування вибору оптимальної системи оподаткування для адвокатів.

Виклад основного матеріалу

Відповідно до статті 1 Закону України «Про адвокатуру та адвокатську діяльність», 


\section{Теорія, історія держави і права, конституційне право}

адвокат - це фізична особа, яка здійснює адвокатську діяльність на підставах та в порядку, що передбачені вищезазначеним Законом [1]. При цьому адвокатська діяльність - це незалежна професійна діяльність адвоката щодо здійснення захисту, представництва та надання інших видів правової допомоги клієнту. Такими видами правової допомоги є види адвокатської діяльності 3 надання правової інформації, консультацій і роз'яснень $з$ правових питань, правового супроводу діяльності клієнта, складення заяв, скарг, процесуальних та інших документів правового характеру, спрямованих на забезпечення реалізації прав, свобод і законних інтересів клієнта, недопущення їх порушень, а також на сприяння їх відновленню в разі порушення.

Ч.1, Ч.2 ст.13 Закону України «Про адвокатуру та адвокатську діяльність» [1] передбачають, що адвокат, який здійснює адвокатську діяльність індивідуально, є самозайнятою особою. Він може відкривати рахунки в банках, мати печатку, штампи, бланки (у тому числі ордера) із зазначенням свого прізвища, імені та по батькові, номера і дати видачі свідоцтва про право на заняття адвокатською діяльністю.

Відповідно до пп.14.1.226 п.14.1 ст.14 Податкового кодексу України самозайнята особа - це платник податку, який є фізичною особою - підприємцем або провадить незалежну професійну діяльність за умови, що така особа не є працівником у межах такої підприємницької чи незалежної професійної діяльності [2]. Щодо незалежної професійної діяльності, то це участь фізичної особи у науковій, літературній, артистичній, художній, освітній або викладацькій діяльності, діяльність лікарів, приватних нотаріусів, приватних виконавців, адвокатів, арбітражних керуючих (розпорядників майна, керуючих санацією, ліквідаторів), аудиторів, бухгалтерів, оцінщиків, інженерів чи архітекторів, особи, зайнятої релігійною (місіонерською) діяльністю, іншою подібною діяльністю за умови, що така особа не $є$ працівником або фізичною особою-підприємцем та використовує найману працю не більш як чотирьох фізичних осіб. 3 цього випливає, що фізична особа, яка здійснює незалежну адвокатську діяльність, не є підприємцем у межах своєї професійної діяльності.

Відповідно до п. 65.9 ст. 65 Податкового кодексу України, якщо фізична особа зареєстрована як підприємець та при цьому така особа провадить незалежну професійну діяльність, то вона обліковується у контролюючих органах як фізична особа-підприємець з ознакою провадження незалежної професійної діяльності [2]. Тобто адвокати можуть сплачувати податки пов'язані з незалежною їх професійною діяльністю як фізична особа-підприємець 3 ознакою провадження незалежної професійної діяльностi.

Облік самозайнятих осіб здійснюеться шляхом внесення до Державного реєстру фізичних осіб - платників податків записів про державну реєстрацію або припинення підприємницької діяльності, незалежної професійної діяльності, перереєстрацію, постановку на облік, зняття з обліку, внесення змін стосовно самозайнятої особи, а також вчинення інших дій, які передбачені Порядком обліку платників податків, зборів.

Для взяття на облік адвокат, який має намір провадити незалежну професійну діяльність, повинен подати заяву та документи особисто (надіслати рекомендованим листом $з$ описом вкладення) або через уповноважену особу до контролюючого органу за місцем постійного проживання. Згідно 3 п. 6.7 «Порядку обліку платників податків і зборів» [3] для взяття на облік фізична особа, яка має намір провадити незалежну професійну діяльність, у строк 10 календарних днів після державної реєстрації (реєстрації) незалежної професійної діяльності, зобов'язаний подати особисто або через уповноважену особу до контролюючого органу за місцем свого постійного проживання: заяву за формою № 5-ОПП та копію свідоцтва про право на заняття адвокатською діяльністю. При подачі документів пред'являються оригінали зазначених документів та паспортний документ. У разі подання документів поштовим відправленням копії документів повинні бути засвідчені нотаріально або органом, який здійснив реєстрацію незалежної професійної діяльності. 
У разі подання документів представником додатково подається примірник оригіналу (нотаріально засвідчена копія) документа, що засвідчує його повноваження.

Якщо адвокат провадить незалежну професійну діяльність індивідуально (не в складі державної спеціалізованої установи чи іншої юридичної особи) не 3 дати видачі відповідного свідоцтва, то для підтвердження періодів, протягом яких незалежна професійна діяльність не провадилась, подається документ відповідного уповноваженого органу чи витяг з реєстру, яким забезпечується реєстрація незалежної професійної діяльності, із зазначенням дат зупинення та поновлення права на заняття незалежною професійною діяльністю або дат зміни організаційної форми відповідної діяльності [4].

Контролюючий орган може відмовити в розгляді документів, поданих для взяття на облік особи, яка здійснює незалежну професійну діяльність, у разі:

- наявності обмежень на провадження незалежної професійної діяльності, встановлених законодавством;

- коли документи подані за неналежним місцем обліку;

- коли документи не відповідають встановленим вимогам, подані не в повному обсязі або коли зазначені в різних документах відомості є взаємно невідповідними;

- коли фізична особа вже взята на облік як самозайнята особа;

- неподання для реєстрації особою, яка має намір провадити незалежну професійну діяльність, свідоцтва про реєстрацію чи іншого документа (дозволу, сертифіката тощо), що підтверджує право фізичної особи на провадження незалежної професійної діяльності.

Після усунення причин, що були підставою для відмови у взятті на облік самозайнятої особи, що здійснює професійну діяльність, фізична особа може повторно подати документи для взяття на облік.

Взяття на облік адвокатів, які мають намір займатися адвокатською діяльністю індивідуально, здійснюється у день отримання від них заяви за формою № 5-ОПП. Підтвердженням реєстрації є довідка про взяття на облік платника податків, яка видаєть- ся наступного робочого дня 3 дня взяття на облік. У довідці про взяття на облік фізичної особи, яка провадить незалежну професійну діяльність, перед прізвищем, ім'ям та по батькові обов'язково вказується вид професійної діяльності, зокрема «Адвокат» [5, с.5].

Довідка про взяття на облік самозайнятої особи втрачає чинність з моменту виникнення змін у даних про фізичну особу, які зазначаються у такій довідці, та підлягає заміні у контролюючому органі.

Порядок оподаткування доходів для фізичних осіб, що провадять незалежну професійну діяльність як адвокати, встановлено ст. 178 Податкового кодексуУкраїни. А саме, особи, які мають намір здійснювати незалежну професійну діяльність, зобов'язані стати на облік у контролюючих органах за місцем свого постійного проживання як самозайняті особи та отримати довідку про взяття на облік. Доходи, отримані протягом календарного року від провадження незалежної професійної діяльності, оподатковуються за ставкою, визначеною п. 167.1ст. 167 Податкового кодексу України, тобто 18 відсотків [2].

Оподатковуваним доходом вважається сукупний чистий дохід, тобто різниця між доходом і документально підтвердженими витратами, необхідними для провадження певного виду незалежної професійної діяльності. У разі неотримання довідки про взяття на облік адвокатом, який здійснюе адвокатську діяльність індивідуально, об'єктом оподаткування є доходи, отримані від такої діяльності без урахування витрат.

Згідно 3 п. 178.4 ст. 178 Податкового кодексу України фізичні особи, які провадять незалежну професійну діяльність, а також іноземці та особи без громадянства, які стали на облік у контролюючих органах як самозайняті особи та $є$ резидентами, подають податкову декларацію за результатами звітного року відповідно до цього розділу у строки, передбачені для платників податку на доходи фізичних осіб, у якій поряд 3 доходами від провадження незалежної професійної діяльності мають зазначати інші доходи 3 джерел їх походження з України та іноземні доходи. 


\section{Теорія, історія держави і права, конституційне право}

Фізичні особи, які провадять незалежну професійну діяльність, зобов’язані вести облік доходів і витрат від такої діяльності. Облік доходів і витрат може вестися в паперовому та/або електронному вигляді, у тому числі через електронний кабінет. Типова форма такого обліку та порядок його ведення визначаються центральним органом виконавчої влади, що забезпечує формування та реалізує державну фінансову політику.

Для адвокатів, які здійснюють адвокатську діяльність індивідуально, спрощена система оподаткування є більш вигідною, ніж загальна.

Відповідно до п. 291.4 ст. 291 Податкового кодексу України, до суб'єктів господарювання, які застосовують спрощену систему оподаткування, обліку та звітності належать [2]:

1) фізичні особи - підприємці, які не використовують працю найманих осіб, здійснюють виключно роздрібний продаж товарів 3 торговельних місць на ринках та/ або провадять господарську діяльність 3 надання побутових послуг населенню і обсяг доходу яких протягом календарного року не перевищує 167 розмірів мінімальної заробітної плати, встановленої законом на 1 січня податкового (звітного) року. Зокрема, станом на 1 січня 2021 року розмір мінімальної заробітної плати становить 6000 грн.

2) фізичні особи - підприємці, які здійснюють господарську діяльність 3 надання послуг, у тому числі побутових, платникам єдиного податку та/або населенню, виробництво та/або продаж товарів, діяльність у сфері ресторанного господарства, за умови, що протягом календарного року відповідають сукупності таких критеріїв: не використовують працю найманих осіб або кількість осіб, які перебувають з ними у трудових відносинах, одночасно не перевищуе 10 осіб; обсяг доходу не перевищує 834 розміри мінімальної заробітної плати, встановленої законом на 1 січня податкового (звітного) року.

3) фізичні особи - підприємці, які не використовують працю найманих осіб або кількість осіб, які перебувають з ними у трудових відносинах, не обмежена та юридичні особи - суб'єкти господарювання будь-якої організаційно-правової форми, у яких протягом календарного року обсяг доходу не перевищує 1167 розмірів мінімальної заробітної плати, встановленої законом на 1 січня податкового (звітного) року.

Спрощена система оподаткування надає можливість адвокату зосередити увагу на зайнятті адвокатською діяльністю, наданні професійної правничої допомоги, а не приділяти свій час організаційним питанням щодо оподаткування.

\section{Висновок}

Адвокат як фізична особа, яка надає адвокатські послуги на підставах та в порядку, що передбачені Законом України «Про адвокатуру та адвокатську діяльність», здійснює адвокатську діяльність індивідуально і вважається самозайнятою особою, що здійснює професійну діяльність. Адвокати, які здійснюють індивідуальну адвокатську діяльність, зобов'язані стати на облік у податкових органах за місцем свого постійного проживання як самозайняті особи, що здійснюють професійну діяльність. Також адвокат має законодавчу можливість зареєструватися як фізична особа підприємець та провадити незалежну професійну діяльність, ставши на облік у податкових органах як платник єдиного податку першої або другої групи. При обранні спрощеної системи оподаткування адвокат полегшує собі механізм оподаткування та зможе приділяти більше уваги наданню професійної правничої допомоги клієнтам.

\section{Лiтература \\ 1. Про адвокатуру та адвокатську ді-} яльність: Закон України від 5.07.2012 р.№ 5076-VI. Відомості Верховної Ради України. 2013. № 27. Ст. 282.

2. Податковий кодекс України: Закон України від 02.12.2010 р. № 2755-VI. Відомості Верховної Ради України 2011 р., № 13, / № 13-14, № 15-16, № 17. Ст. 112.

3. Порядок обліку платників податків i зборів: Наказ Міністерства фінансів України від 09.12.2011 р. № 1588. Режим доступу: https://zakon.rada.gov.ua/laws/show/z156211 \#Text. 
4. Про затвердження Змін до Порядку обліку платників податків і зборів: Наказ Міністерства фінансів України від 24.06.2020 р. № 323. Режим доступу: https://zakon.rada. gov.ua/laws/show/z0606-20\#Text

5. Гвоздій В. Методичні рекомендації 3 оподаткування адвокатської діяльності. Х.: Фактор, 2017. 32 с.

\section{LEGAL PRINCIPLES OF TAXATION OF INDIVIDUAL ATTORNEY ACTIVITY: THEORETICAL ASPECTS}

Scientific labour is devoted research of legal principles and theoretical positions of taxation of individual attorney activity. An author is analyse the theoretical aspects of determination of legal status of payer of tax during realization of individual attorney activity and the substantive provisions of legislation are exposed in relation to the terms of registration, account and declaration of attorney activity, by the concerned persons and physical persons which carry out professional activity. The features of realization of individual attorney activity are outlined as a separate type of entrepreneurial or professional activity.

Failings and blanks of modern tax legislation are exposed in relation to declaration of incomes of physical persons of purchased by realization of attorney activity on territory of Ukraine, the ways of removal of these failings are explained and thrown out suggestions of improvement of statutory provisions. Bringing of norms of current legislation of Ukraine is offered to conformity with the modern European standards, that will provide the proper implementation taxpayers the tax obligations, receipt of taxes, collections and obligatory payments, in the state or local budget, and also will foresee defence of rights for taxpayers the concerned persons or physical persons which carry out professional activity, in particular, attorneys.

Key words: advocacy, institute of advocacy, advocacy activity, physical person which carries out professional activity, concerned person, individual businessman, taxation of advocacy activity. 